\title{
Brand Management and Growth in Small Mexican Businesses
}

\author{
Gonzalo Maldonado Guzmán \\ Universidad Autónoma de Aguascalientes \\ Centro de Ciencias Económicas y Administrativas \\ Departamento de Mercadotecnia \\ Edith Reyes Ruiz \\ Universidad Autónoma de Coahuila \\ Facultad de Mercadotecnia \\ Jesús Francisco Mellado Siller \\ Universidad Autónoma de Coahuila \\ Facultad de Mercadotecnia
}

\begin{abstract}
Brand management is a contemporary topic in the marketing literature. A proof of this are the scarce published investigations that analyze and discuss this key construct and there are even fewer published researches that link brand management with the growth of small businesses since both constructs have usually been analyzed and discussed in big enterprises by investigators, scholars and professionals in the field of marketing even when small companies represent more than $90 \%$ of all enterprises in any country of the world. The main objective of this empirical research is the analysis and discussion of the existing link between brand management and the level of growth of small enterprises. For this, a sample of 300 small businesses was used and a model of structural equations was used in order to know more deeply the current connection between brand management and the level of growth of small businesses. The results obtained show that brand management have a positive and significant effect in the level of growth of small businesses.
\end{abstract}

Keywords: Brand, brand management, growth, small business.

\section{Introduction}

The analysis and discussion of brand management is relatively new topic in the marketing literature and it is normally considered not only as a key factor of the success of enterprises (de Chernatony \& McDonald, 2003), but also as an essential element that creates a higher level of growth in small businesses (Eggers et al., 2013). Moreover, brand management is considered by different investigators, scholars and professionals as a basic resource for organizations, especially for small enterprises, when the different products or services that they offer in the marker satisfy the needs of clients and consumers, and they fulfill the promises established in the media and advertising (Fisher-Buttinger \& Vallaster, 2008).

Accordingly, a high percentage of the papers published in the current marketing literature, has focused mostly in the analysis and discussion of brand management in big enterprises and international brands (Berthon et al., 2008). Only a few research papers have paid attention to small businesses (Jones et al., 2005; Abimbola \& Kocak, 2007; Potter, 2010), even when small enterprises provide employment to more than 71 million people and represent around $99.8 \%$ of the enterprises established in the European Union (Stawinska, 2011). In the case of Mexico, this type of companies employs slightly over $71.2 \%$ of all workers in the country $\left(21^{\prime} 576,350\right)$, and this represents $99.8 \%$ of all the economic units established (4’230,745) (INEGI, 2015).

For these reasons, it is difficult to understand why the current marketing literature has few published researches about brand management in small enterprises, and even more when the investigations by Napoli (2006) as well as Wong and Merrilees (2008), analyzed with great detail the brand management in small businesses and considered that the number of academic papers should be increased in this area. Furthermore, in the context of small enterprises there is a classification of brand management based on the typology of this important kind of company (Wong \& Merrilees, 2005), which suggests that small businesses have the possibility of creating their own brand management and improve the reputation level of the brand of their products or services with their available resources at any time (Abimbola \& Vallester, 2007). 
Moreover, the growth of enterprises has usually been considered in the current marketing literature as an essential measurement of business performance and success (Carton \& Hofer, 2006). Basically, the growth of small companies is still one of the least analyzed and discussed elements by researchers, scholars and professionals of marketing in investigation papers about brand management (Davidsson et al., 2005). For this reason, it is important that researchers, scholars and professionals of marketing explore brand management as one of the essential elements that enable the growth of small businesses (Eggers et al., 2013), especially considering the close link between the brand and the company sales (Inskip, 2004).

In this regard, brand management not only provides several benefits to consumers but it also guarantees a financial performance and a growth of small enterprises (Grace \& O'Cass, 2002). Moreover, there are few investigations that analyze the connection between brand management and business growth. Thus, the main contribution of this empirical research is the analysis and discussion of the effects of brand management in the growth of small enterprises, just as it is recommended by Napoli (2006), Wong and Merrilees (2008), Abimbola and Vallester (2007), as well as Eggers et al. (2013), especially in a country with an emerging economy, which is the case of Mexico.

\section{Literature Review}

The importance of the brand as an essential activity of enterprises has been analyzed and discussed scarcely in the current marketing literature (Reijonen et al., 2012), even when this concept refers practically to the essence of marketing strategies and activities carried out by enterprises to stand out from their competitors (Wong \& Merrilees, 2005). Therefore, the brand is usually created and managed by enterprises, particularly small firms, as an integral part of the processes of the organization that is constantly interacting with clients and consumers (Urde, 1999), which can create sustainable, competitive advantages, as well as a significant incremental in the level of growth and profitability (Urde, 1994; Wong \& Merrilees, 2005).

In this regard, brand management is considered as one of the few elements that play a fundamental role in the growth of enterprises, especially in small businesses (Wong \& Merrilees, 2005). However, there are relatively few investigations developed by researchers, scholars and professionals of marketing that link both constructs, and some of the published investigations about brand management suggest that this has an indirect influence in the financial development and, consequently, in their level of growth (Wong \& Merrilees, 2008). Similarly, within the context of nonprofit organizations, some recently published investigations found a positive and strongly significant link, between brand management and business performance as well as with the growth of enterprises (Napoli, 2006).

Additionally, Dobbs and Hamilton (2007) identified in the marketing and business sciences literature, six different approaches for the study and analysis of growth in small enterprises: stochastic, descriptive, evolutional, based on resources, learning and deterministic. Likewise, in most of the scarce empirical researches that have been published, the growth of small businesses can be explained by factors that are closely related to the management of business strategies (i.e. growth goals, staff recruiting and improvement, development of new products, financial resources, business internationalization, collaboration, and flexibility), characteristics of managers (motivation, education, and experience), specific factors of environment/industry (demand and supply variations), and characteristics of the enterprise (size and years in business) (Dobbs and Hamilton, 2007).

Accordingly, in the context of small enterprises, managers and/or owners of businesses usually play a key role in the growth (or lack of growth) of their companies, because depending on the skills, motivation and goals they have regarding their organization they will have crucial effects about decision-making, so small enterprises can give the qualitative jump and become big companies or simply decide to stay where they are (Walker \& Brown, 2004). As a result of this, there are some empirical papers that indicate that managers and/or owners of small businesses, generally have different goals and some of them are not directly related to the growth of the company and most managers and/or owners, do not have as a main objective to achieve a type of growth in their organization (Greenbank, 2001).

On the other hand, the same investigations establish that a high percentage of managers and/or owners of small enterprises, are too happy with the size of their companies and they have not considered to carry out any business activities in a short term that can make them a big enterprise (Walker \& Brown, 2004). However, there is also empirical evidence in the current marketing literature that some of the managers and/or owners of small businesses, actually have in their business goals to achieve a higher level of growth for their small companies. This is why some managers and/or owners try to take advantage of the different opportunities they have to reach the goals and objectives, they established which may be to attain a significant growth for their small businesses (Reijonen et al., 2012).

In this context, it is very important that small enterprises achieve better levels of growth because they are the most important sector, not only in the creation of jobs but also in the advancement of economic growth and the improvement of life conditions of society in general (Reijonen et al., 2012). 
Therefore, managers and/or owners of small businesses will have to control more efficiently the brand of their products or services, as well as to carry out innovations in their brand (Reijonen et al., 2012), because the growth of small enterprises is normally evaluated through the changes in the size of companies. As long as small companies improve their level of market participation, they will have a higher level of growth.

Furthermore, the measurement of growth of small enterprises usually includes the changes in the volumes of business, goods, number of employees, participation of the market, the market value of the enterprise, sales of products and/or services, as well as different measurements of the profits or earnings of companies (Murphy et al., 1996; Dobbs \& Hamilton, 2007). Consequently, it is possible to use only one growth measurement for small businesses or combine them although some researchers, scholars and professionals of marketing consider that it is much better the use of a combination of different measurement scales of growth, as this decision is based primarily on the intention of getting a better understanding of the level of growth that small enterprises can attain (Reijonen et al., 2012).

In this set of ideas, the different growth measurements of small enterprises represent different aspects of their growth, regarding the different objectives and goals that managers and/or owners have. For example, Komppula (2004) as well as Reijonen and Komppula (2007), concluded in their papers that the growth in sales is one of the best growth measurements of small businesses, and it is the measurement that most managers and/or owners of small enterprises, consider whereas the increase in the number of employees is not usually considered as a good measurement of small companies, mostly for different key reasons including (and probably the most important one) the high costs of workers and their quality (Reijonen et al., 2012).

On the other hand, brand management is not usually considered as a business strategy in most small enterprises (Inskip, 2004), since almost all managers and/or owners of small businesses traditionally consider that these activities correspond only to big companies (Eggers et al., 2013). Similarly, the significant increase of the level of competitiveness demanded by market along with the consolidation, shown by the industry and the increase of the sophistication of products and services demanded by consumers, are constantly exerting pressure on several small enterprises to incorporate brand management activities as a business strategy, that allow their products and/or services to have a better level of positioning and acceptance in the markets where they participate (Eggers et al., 2013).

However, the limitation of resources and the inadequate knowledge that enterprises have regarding the construction of the brand and the brand management, is causing that small enterprises do not have the required levels of sales and profit in order to implement all the activities related to brand management (Calabro, 2005). Moreover, some researchers, scholars and professionals in the field of marketing have stated that small businesses do not necessarily need a big budget to build up and manage adequately the brand of their products or services (Krake, 2005; Wong \& Merrilees, 2005), but they often can be more efficient in the brand management of the organization which can produce a significant increase in their level of business growth (Inskip, 2004).

Thus, the impact of efficiency in brand management could be a significant decrease in the costs of sales in small enterprises and, with this, a decline in the price to obtain products or services from their clients and consumers and, consequently, boost not only the margin of profit but also the opportunities of growth of small businesses (Calabro, 2005). Therefore, the growth of small enterprises could be achieved if this type of companies focus their marketing activities to improve their market position, develop new markets, promote their products or services, cut the price of their products or services, differentiate their products or services from their main competitors and distribute their products or services more efficiently (Wind \& Robertson, 1983; Carson \& McCartan-Quinn, 1995; Pearce \& Michael, 1996; Carter \& Tzokas, 1999).

Finally, the ability of managers and/or owners of small enterprises to manage the level of growth adequately will be strongly influenced for the compatibility of the brand management practices of their products and services, as well as the practices of entrepreneurial behavior that managers and/or owners have (Hatch \& Schultz, 2008). Consequently, brand management is becoming an essential element that can reinforce without difficulties the growth of small enterprises (Arthur W. Page Society, 2007; Eggers et al., 2013). Therefore, considering the information mentioned above, it is possible to establish the third research hypothesis:

\section{H1: The higher level of brand management, the higher level of business growth}

\section{Methodology}

In order to answer the research hypotheses established in this investigation about small and medium-sized enterprises in Aguascalientes State (Mexico), it was considered relevant to use the 2017 business directory of the Sistema de Información Empresarial Mexicano (System of Mexican Business Information), which had 1,427 registered enterprises, each one containing from 5 to 250 workers on January 31, 2017. 
Moreover, an instrument of data collection (i.e. a survey) to retrieve information was designed to be answered specifically by managers and/or owners of small enterprises. It was carried out as a personal interview with a sample of 300 small enterprises, selected through a random sampling with a maximum error of $\pm 5 \%$ and a level of reliability of 95\%, which represents slightly over $21 \%$ of the enterprises registered in Aguascalientes. The interviews took place between February and April of 2017.

Moreover, a scale developed by Baumgarth (2010) was used for the measurement of brand management in small enterprises. The researcher considered that brand management can be measured through four dimensions: Value, which was measured through a five-item scale; Norms, which were measured through a six-item scale; Artifacts, which were measured through a four-item scale; and Behaviors, which were measured through a four-item scale. All the items of the four dimensions used were measured through a Likert-type scale of five positions from " 1 = completely disagree" to " $5=$ completely agree" as limits. Regarding growth, it was measured through the sales made by small enterprises in 2017 (Autio \& Lumme, 1998; Ballow et al., 2004; Salojärvi et al., 2005; Linder, 2006; Carneiro, 2007; Kruger \& Johnson, 2009), because in order to estimate the potential of growth it is common to consider a qualitative evaluation of managers and sales are the main indicator (Autio \& Lumme, 1998).

Likewise, a Second-Order Confirmatory Factor Analysis (SOCFA) was carried out to evaluate the reliability and validity of the scale of brand management, by using the method of maximum likelihood with the software EQS 6.2 (Bentler, 2005; Brown, 2006; Byrne, 2006). Thus, the reliability was measured with Cronbach's alpha as well as the Composite Reliability Index (CRI) (Bagozzi \& Yi, 1988). The results obtained are shown in Table 1 and they indicate that the theoretical model analyzed has a good adjustment of data $\left(S-B X^{2}=843.698 ; d f=142 ; p=0.000 ; N F I=0.895\right.$; $N N F I=0.898 ; C F I=0.913 ; R M S E A=0.079)$. Likewise, the values of Cronbach's alpha and the CRI are higher than 0.7, which indicates presence of the reliability on the scale of brand management (Nunally \& Bernstein, 1994; Hair et al., 2010).

Accordingly, the results obtained from the SOFCA indicate that all the items of the factors related are significant $(\mathrm{p}<$ 0.01). The value of all the standardized factorial loads is higher than 0.6 (Bagozzi \& Yi, 1988), and the Extracted Variance Index (EVI) of each pair of constructs of the theoretical model of brand management and small business growth has a value over 0.5 (Fornell \& Larcker, 1981). These values indicate that the theoretical model has a good adjustment of data and provide evidence of the presence of convergent validity. 
Table 1. Internal consistency and convergent validity of the theoretical model

\begin{tabular}{|c|c|c|c|c|c|c|}
\hline Variable & Indicator & $\begin{array}{l}\text { Factorial } \\
\text { Loading }\end{array}$ & $\begin{array}{l}\text { Robust t- } \\
\text { Value }\end{array}$ & $\begin{array}{c}\text { Cronbach's } \\
\text { Alpha }\end{array}$ & CRI & EVI \\
\hline $\begin{array}{l}\text { Value } \\
\text { (F1) }\end{array}$ & $\begin{array}{l}\text { VM1 } \\
\text { VM2 } \\
\text { VM3 } \\
\text { VM4 } \\
\text { VM5 } \\
\end{array}$ & $\begin{array}{l}0.968 * * * \\
0.971 * * * \\
0.959 * * * \\
0.940 * * * \\
0.909 * * *\end{array}$ & $\begin{array}{c}1.000^{\mathrm{a}} \\
47.493 \\
43.412 \\
38.274 \\
32.360 \\
\end{array}$ & 0.978 & 0.979 & 0.902 \\
\hline $\begin{array}{l}\text { Norms } \\
\text { (F2) }\end{array}$ & $\begin{array}{l}\text { NM1 } \\
\text { NM2 } \\
\text { NM3 } \\
\text { NM4 } \\
\text { NM5 } \\
\text { NM6 }\end{array}$ & $\begin{array}{l}0.881 \text { *** } \\
0.855^{* * *} \\
0.867 * * * \\
0.836 * * * \\
0.776^{* * * *} \\
0.745 * * * \\
\end{array}$ & $\begin{array}{c}1.000^{\mathrm{a}} \\
20.283 \\
20.847 \\
19.399 \\
16.986 \\
15.878\end{array}$ & 0.928 & 0.929 & 0.686 \\
\hline $\begin{array}{l}\text { Artifacts } \\
\text { (F3) }\end{array}$ & $\begin{array}{l}\text { AM1 } \\
\text { AM2 } \\
\text { AM3 } \\
\text { AM4 }\end{array}$ & $\begin{array}{l}0.966 * * * \\
0.974 * * * \\
0.979 * * * \\
0.968 * * *\end{array}$ & $\begin{array}{c}1.000^{\mathrm{a}} \\
48.076 \\
50.033 \\
45.663\end{array}$ & 0.984 & 0.985 & 0.944 \\
\hline Behaviors (F4) & $\begin{array}{l}\text { CM1 } \\
\text { CM2 } \\
\text { CM3 } \\
\text { CM4 }\end{array}$ & $\begin{array}{l}0.953 * * * \\
0.930 * * * \\
0.891 * * * \\
0.812 * * *\end{array}$ & $\begin{array}{l}1.000^{\mathrm{a}} \\
32.223 \\
27.567 \\
21.307\end{array}$ & 0.942 & 0.943 & 0.807 \\
\hline Brand Management & $\begin{array}{l}\text { F1 } \\
\text { F2 } \\
\text { F3 } \\
\text { F4 } \\
\end{array}$ & $\begin{array}{l}0.640 * * * \\
0.772 * * * \\
0.854 * * * \\
0.961 * * *\end{array}$ & $\begin{array}{c}5.546 \\
9.651 \\
13.492 \\
16.381 \\
\end{array}$ & 0.885 & 0.886 & 0.665 \\
\hline \multicolumn{7}{|c|}{$S-B X^{2}(\mathrm{df}=142)=843.698 ; \mathrm{p}<0.000 ; \mathrm{NFI}=0.895 ; \mathrm{NNFI}=0.898 ; \mathrm{CFI}=0.913 ; \mathrm{RMSEA}=0.079$} \\
\hline
\end{tabular}

\section{Results}

In order to answer the hypothesis established in this empirical investigation, a structural equations model was applied with software EQS 6.2 (Bentler, 2005; Byrne, 2006; Brown, 2006). Regarding the nomological validity of the theoretical model of brand management and small business growth, it was examined through the Chi-square test, which compared the results obtained between the theoretical model and the measurement model. Such results indicate that the differences between both models are not significant, which can offer an explanation of the relations observed among the latent constructs (Anderson \& Gerbing, 1988; Hatcher, 1994). Table 2 shows the results in a more detailed way the implementation of the model of structural equations. 
Table 2. Results of the structural equation model of second order

\begin{tabular}{|l|c|c|c|}
\hline \multicolumn{1}{|c|}{ Hypothesis } & Structural Relationship & $\begin{array}{c}\text { Standardized } \\
\text { Coefficient }\end{array}$ & $\begin{array}{c}\text { Robust t- } \\
\text { Value }\end{array}$ \\
\hline $\begin{array}{l}\text { H1: The higher level of brand } \\
\text { management, higher level of } \\
\text { small business growth. }\end{array}$ & Brand M. $\rightarrow$ Growth & $0.614 * * *$ & 30.847 \\
\hline$S-B X^{2}(\mathrm{df}=135)=817.664 ; \mathrm{p}<0.000 ; \mathrm{NFI}=0.893 ; \mathrm{NNFI}=0.901 ; \mathrm{CFI}=0.915 ; \mathrm{RMSEA}=0.079$ \\
\hline
\end{tabular}

Table 2 shows the results of the confirmation of the research hypothesis $\mathbf{H}_{1}(\beta=0.614, \mathrm{p}<0.01)$. The results indicate that brand management has positive significant effects in the small business growth. Therefore, it is possible to conclude that the different brand management activities that small enterprises adopt and implement, will affect their level of business growth in a positive way.

\section{Conclusions And Discussion}

The results obtained in this empirical research allow us to conclude in two main aspects. On one hand, the brand management of products or services manufactured by small enterprises is essential so companies have more possibilities to obtain better results. Therefore, it can be concluded that brand management in small businesses should not be considered only as another business strategy, but rather as part of the everyday activities that small companies have to carry out as this will facilitate the attainment of better business results, as well as a better market position, more and better competitive advantages, a better level of business performance and a significant increase in their level of growth which could facilitate the creation of a scale economy. On the other hand, considering that a high percentage of small enterprises do not have as a main objective or as an essential goal to obtain a higher level of business growth, it will be necessary that managers and/or owners of this important business sector change their paradigm and incorporate in their objectives and goals to achieve a sustained growth. Therefore, it is possible to conclude that the level of growth of small enterprises will be not only a basic conditions to achieve a scale economy, but also for small enterprises to be able to continue in the market where they participate. Otherwise, if small enterprises cannot have a significant growth, it will be very difficult that they survive.

Additionally, the results obtained in this empirical research also have a series of implications that are necessary to establish. One of the first implications is that most small enterprises, not only in Mexico, but in any other developing country in the world, do not usually have a patent registration of their products or services. That is why, as a first step, managers and/or owners of small enterprises have to carry out the necessary actions for the registration of the brand of their products or services and, secondly, adopt and implement all the activities related to the efficiency and effectiveness of brand management because this will allow them not only to obtain more and better competitive advantages but also to increase their level of business growth.

A second implication derived of these results is that managers and/or owners of small enterprises will have to implement brand management activities in all the organization as a whole with the employees and workers of small enterprises as the first ones to be convinced of the different advantages that the organization has with the adoption of this type of activities. Otherwise, it will be very complicated to improve the efficiency in the brand management of their products or services. Consequently, in order to achieve an efficiency and effectiveness in brand management it will be necessary that managers and/or owners include all the departments or functional areas of the company in these activities allowing with this type of actions that small enterprises can achieve a significant increase of their level of growth.

A third implication of the results obtained is that managers and/or owners of small enterprises have to look for courses or training workshops for their workers and employees regarding brand management or take advantage of the courses or training workshops offered by government branches and business associations about brand management. This will allow managers and/or owners as well as employees and workers of the organization to be the main advocates of efficiency and effectiveness of the brand management of their products or services of small enterprises which will help small enterprises not only to have a higher level of business return but also a significant increase in their level of growth.

Finally, a fourth implication of the results obtained is that managers and/or owners of small enterprises have to create the necessary working conditions so employees and workers can carry out the activities related to the brand 
management of their products or services of the organization. The aim of this is to phase out the negative attitudes that workers and employees may have or convince the reluctant staff about the different virtues that brand management has for all the workforce of the organization because if managers and/or owners of small enterprises do not have the ability to convince all the staff of the organization about the importance of brand management activities then the growth of small enterprises will be at risk as well as the very survival of the organization.

Accordingly, this empirical research has some limitations that are necessary to establish at this point. The first one is about the sample used as only small businesses that had between five and 250 workers were considered. That is why future investigations will have to consider small enterprises with less than five workers in order to confirm the results obtained. The second limitation is that the questionnaire applied to collect the data only considered small enterprises in the state of Aguascalientes (Mexico) so further researches will need to apply the same questionnaire to other small enterprises established of all the country and even other Latin American countries in order to verify if the results are similar or not to the ones obtained in this investigation.

A third limitation are the scales used for the measurement of both brand management and the growth of small enterprises as it was used a scale of only four factors and 19 items for the measurement of brand management and only one item for the measurement of growth. Following investigations might ponder the use of a different scale to measure both constructs and confirm the results obtained. A fourth limitation is that only qualitative variables were considered for the measurement of brand management and growth so in future investigations it will be necessary to consider quantitative scales or hard data to have the opportunity to prove or disprove the presence of statistically significant differences in the results obtained in small enterprises.

A fifth limitation is that the instrument applied to collect data only considered managers and/or owners of the small enterprises that were selected. This created the assumption that they have a deep understanding about brand management activities and the growth of the organization. Future research papers will need to apply the same questionnaire to workers, employees and co-workers of the organization in order to confirm the results obtained. Finally, the last limitation is that several small enterprises considered that the information requested was confidential so the results obtained do not necessarily reflect the reality of brand management and business growth.

\section{References}

Abimbola, T., \& Kocak, A. (2007). Brand, organizational identity and reputation: SMEs as expressive organizations: A resourced-based perspective. Qualitative Market Research: An International Journal, 10(1), 416-430.

Abimbola, T., \& Vallester, C. (2007). Brand, organizational identity and reputation in SMEs: An overview. Qualitative Market Research: An International Journal, 10(1), 341-348.

Anderson, J., \& Gerbing, D. (1988). Structural equation modeling in practice: a review and recommended two-step approach. Psychological Bulletin, 13, 411-423.

Arthur W. Page Society (2007). The Authentic Enterprise: An Arthur W. Page Society Report. New York, NY: Arthur W. Page Society.

Auttio, E., \& Lumme, A. (1998). Does the innovator role affect the perceived potential for growth? Analysis of four types of new, technology-based firms. Technology Analysis \& Strategic Management, 10(1), 41-54.

Bagozzi, R., \& Yi, Y. (1988). On the evaluation of structural equation models. Journal of the Academy of Marketing Science, 16(1), 74-94.

Ballow, J.J., McCarthy, B., \& Molnar, M.J. (2004). New concepts in value-based management: TRS mapping and total economic profit. Wellesley, MA: Accenture Institute for High Performance Business.

Baumgarth, C. (2010). Living the brand: Brand orientation in the business-to-business sector. European Journal of Marketing, 44(5), 653-671.

Bentler, P. (2005). EQS 6 Structural Equations Program Manual. Encino, CA: Multivariate Software.

Berthon, P., Ewing, M.T., \& Napoli, J. (2008). Brand management in small to medium-sized enterprises. Journal of Small Business Management, 46(2), 27-45.

Brown, T. (2006). Confirmatory Factor Analysis for Applied Research. New York, NY: The Guilford Press.

Byrne, B. (2006). Structural Equation Modeling With EQS, Basic Concepts, Applications, and Programming. 2th Edition. London; LEA Publishers.

Calabro, S. (2005). Making the mark. Sales and Marketing Management, 157(1), 38-42.

Carneiro, A. (2007). What is required for growth? Business Strategy Series, 8(1), 51-57.

Carson, D., \& McCartan-Quinn, D. (1995). Non-practice of theoretically based marketing in small business: Issues arising and their implications. Journal of Marketing Theory and Practice, 3(1), 24-31. 
Carter, S., \& Tzokas, N. (1999). Marketing activities and the performance of small firms: A cross-national study of European SMEs. $22^{\text {nd }}$ ISBA National Small Firms Policy and Research Conference Proceedings, 227-246.

Carton, R.B., \& Hofer, C.W. (2006). Measuring Organizational Performance: Metrics for Entrepreneurship and Strategic Management Research. Cheltenham: Edward Elgar Publishing.

Davidsson, P., Achtenhagen, L., \& Naldi, L. (2005). Research on small firm growth: A review. Proceedings of the European Institute of Small Business, 1-18.

de Chernatony, L., \& McDonald, M. (2003). Creating Powerful Brands. 3ed Ed. Oxford: Elsevier/ButterworthHeinemann.

Dobbs, M., \& Hamilton, R.T. (2007). Small business growth: Recent evidence and new directions. International Journal of Entrepreneurial Behaviour \& Research, 13(2), 296-322.

Eggers, F., O’Dwyer, M., Kraus, S., Vallester, C., \& Gülderberg, S. (2013). The impact of brand authenticity on brand trust and SME growth: A CEO perspective. Journal of World Business, 48(1), 340-348.

Fisher-Buttinger, C., \& Vallester, C. (2008). Connecting Branding: Building Brand Equity in a Demanding World. London: John Wiley \& Sons.

Fornell, C., \& Larcker, D. (1981). Evaluating structural equation models with unobservable variables and measurement error. Journal of Marketing Research, 18, 39-50.

Grace, D., \& O'Cass, A. (2002). Brand associations: Looking through the eye of the beholder. Qualitative Market Research: An International Journal, 5(1), 96-111.

Greenbank, P. (2001). Objective setting in the micro-business. International Journal of Entrepreneurship Behaviour \& Research, 7(1), 108-127.

Hair, J.F., Anderson, R.E., Tatham, R.L., \& Black, W.C. (1995). Multivariate Data Analysis with Readings. New York, NY: Prentice-Hall.

Hatch, M.J., \& Schultz, M. (2008). Taking Brand Initiative: How Companies can align their Strategy, Culture and Identity through Corporate Branding? San Francisco: Jossey Bass.

Hatcher, L. (1994). A Step by Step Approach to Using the SAS System for Factor Analysis and Structural Equation Modeling, Cary, NC: SAS Institute Inc.

INEGI (2015). Censos Económicos 2014. México: Instituto Nacional de Geografía.

Inskip, I. (2004). Corporate branding for small to medium-sized businesses: A missed opportunity or an indulgence? Journal of Brand Management, 11(2), 358-365.

Jones, C., Anand, N., \& Alvarez, J.L. (2005). Manufactured authenticity and creative voice in cultural industries. Journal of Management Studies, 42(3), 893-899.

Komppula, R. (2004). Success and growth in rural tourism micro-business in Finland: Financial or life-cycle objectives? In R. Thomas (Ed.), Small Firms in Tourism: International Perspectives. Advances in Tourism Research Series. London: Elsevier.

Krake, F. (2005). Successful brand management in SMEs: A new theory and practical hints. Journal of Product \& Brand Management, 14(2), 228-238.

Kruger, C.J., \& Johnson, R.D. (2009). Assessment of knowledge management growth: A South Africa perspective. Aslib Proceedings: New Information Perspectives, 61(6), 542-564.

Linder, J.C. (2006). Does innovation drive profitable growth? New metrics for a complete picture. Journal of Business Strategy, 27(5), 38-44.

Murphy, G.B., Trailer, J.W., \& Hill, R.C. (1996). Measuring performance in entrepreneurship research. Journal of Business Research, 36(2), 15-23.

Napoli, J. (2006). The impact of non-profit brand orientation on organizational performance. Journal of Marketing Management, 22(3), 673-694.

Nunnally, J.C., \& Bernstein, I.H. (1994). Psychometric Theory. $3^{a}$ Edition. New York, NY: McGraw-Hill.

Pearce, J.A., \& Michael, S.C. (1996). Marketing strategies the make small manufacturing firms recession-resistant. Research at the Marketing-Entrepreneurship Interface, University at Illinois of Chicago Conference Proceedings, 125-136.

Potter, A. (2010). The Authenticity Hoax: How we get Lost Finding Ourselves. New York, NY: Harper.

Reijonen, H., \& Komppula, R. (2007). Perception of success and its effect on s mall firms performance. Journal of Small Business and Enterprise Development, 14(3), 689-701.

Reijonen, H., Laukkanen, T., Komppula, R., \& Touminen, S. (2012). Are growing SMEs more market-oriented and brand-oriented? Journal of Small Business Management, 50(4), 699-716.

Salojärvi, S., Furu, P., \& Sveiby, K.E. (2005). Knowledge management and growth in Finnish SMEs. Journal of Knowledge Management, 9(2), 103-122. 
Stawinska, A. (2011). Key Figures on European Business with a Special Feature on SMEs. Luxemburg: Eurostat/Publications Office of the European Union.

Urde, M. (1994). Brand orientation: A strategy for survival. Journal of Consumer Marketing, 11(1), 18-32.

Urde, M. (1999). Brand orientation a mindset for building brands into strategic resources. Journal of Marketing Management, 15(1), 117-133.

Walker, E., \& Brown, A. (2004). What success factors are important to small business owners? International Small Business Journal, 22(4), 577-594.

Wind, Y., \& Robertson, T.S. (1983). Marketing strategy: New directions for theory and research. Journal of Marketing, 47(1), 12-25.

Wong, B., \& Merrilees, B. (2005). A brand orientation typology for SMEs: A case research approach. Journal of Product \& Brand Management, 14(2), 155-162.

Wong, H.Y., \& Merrilees, B. (2008). The performance benefits of being brand-orientated. Journal of Product \& Brand Management, 17(6), 372-383. 